Pal, K. K. and B. McSpadden Gardener, 2006. Biological Control of Plant Pathogens. The Plant Health Instructor DOI: 10.1094/PHI-A-2006-1117-02.

\title{
Biological Control of Plant Pathogens
}

\author{
Kamal Krishna Pal*, Visiting Scholar, Department of Plant Pathology, Ohio State University, \\ OARDC, Wooster, $\mathrm{OH}$ \\ Brian McSpadden Gardener, Department of Plant Pathology, Ohio State University, OARDC, \\ Wooster, $\mathrm{OH}$ \\ *Permanent address: National Research Centre for Groundnut, Ivnagar Road, PB No. 5, \\ Juangadh-362 001, Gujarat, India
}

\section{Introduction}

Plant diseases need to be controlled to maintain the quality and abundance of food, feed, and fiber produced by growers around the world. Different approaches may be used to prevent, mitigate or control plant diseases. Beyond good agronomic and horticultural practices, growers often rely heavily on chemical fertilizers and pesticides. Such inputs to agriculture have contributed significantly to the spectacular improvements in crop productivity and quality over the past 100 years. However, the environmental pollution caused by excessive use and misuse of agrochemicals, as well as fear-mongering by some opponents of pesticides, has led to considerable changes in people's attitudes towards the use of pesticides in agriculture. Today, there are strict regulations on chemical pesticide use, and there is political pressure to remove the most hazardous chemicals from the market. Additionally, the spread of plant diseases in natural ecosystems may preclude successful application of chemicals, because of the scale to which such applications might have to be applied. Consequently, some pest management researchers have focused their efforts on developing alternative inputs to synthetic chemicals for controlling pests and diseases. Among these alternatives are those referred to as biological controls.

A variety of biological controls are available for use, but further development and effective adoption will require a greater understanding of the complex interactions among plants, people, and the environment. To that end, this article is presented as an advanced survey of the nature and practice of biological control as it is applied to the suppression of plant diseases. This survey will i) describe the various definitions and key mechanisms of biocontrol, ii) explore the relationships between microbial diversity and biological control, iii) describe the current status of research and application of biological controls, and iv) briefly outline future directions that might lead to the development of more diverse and effective biological controls for plant diseases.

\section{Definitions}

The terms "biological control" and its abbreviated synonym "biocontrol" have been used in different fields of biology, most notably entomology and plant pathology. In entomology, it has been used to describe the use of live predatory insects, entomopathogenic nematodes, or 
microbial pathogens to suppress populations of different pest insects. In plant pathology, the term applies to the use of microbial antagonists to suppress diseases as well as the use of hostspecific pathogens to control weed populations. In both fields, the organism that suppresses the pest or pathogen is referred to as the biological control agent (BCA). More broadly, the term biological control also has been applied to the use of the natural products extracted or fermented from various sources. These formulations may be very simple mixtures of natural ingredients with specific activities or complex mixtures with multiple effects on the host as well as the target pest or pathogen. And, while such inputs may mimic the activities of living organisms, nonliving inputs should more properly be referred to as biopesticides or biofertilizers, depending on the primary benefit provided to the host plant. The various definitions offered in the scientific literature have sometimes caused confusion and controversy. For example, members of the U.S. National Research Council took into account modern biotechnological developments and referred to biological control as "the use of natural or modified organisms, genes, or gene products, to reduce the effects of undesirable organisms and to favor desirable organisms such as crops, beneficial insects, and microorganisms", but this definition spurred much subsequent debate and it was frequently considered too broad by many scientists who worked in the field (US Congress, 1995). Because the term biological control can refer to a spectrum of ideas, it is important to stipulate the breadth of the term when it is applied to the review of any particular work.

Published definitions of biocontrol differ depending on the target of suppression; number, type and source of biological agents; and the degree and timing of human intervention. Most broadly, biological control is the suppression of damaging activities of one organism by one or more other organisms, often referred to as natural enemies. With regards to plant diseases, suppression can be accomplished in many ways. If growers' activities are considered relevant, cultural practices such as the use of rotations and planting of disease resistant cultivars (whether naturally selected or genetically engineered) would be included in the definition. Because the plant host responds to numerous biological factors, both pathogenic and non-pathogenic, induced host resistance might be considered a form of biological control. More narrowly, biological control refers to the purposeful utilization of introduced or resident living organisms, other than disease resistant host plants, to suppress the activities and populations of one or more plant pathogens. This may involve the use of microbial inoculants to suppress a single type or class of plant diseases. Or, this may involve managing soils to promote the combined activities of native soil- and plant-associated organisms that contribute to general suppression. Most narrowly, biological control refers to the suppression of a single pathogen (or pest), by a single antagonist, in a single cropping system. Most specialists in the field would concur with one of the narrower definitions presented above. In this review, biological control will be narrowly defined as highlighted above in bold.

\section{Types of interactions contributing to biological control}

Throughout their lifecycle, plants and pathogens interact with a wide variety of organisms. These interactions can significantly affect plant health in various ways. In order to understand the mechanisms of biological control, it is helpful to appreciate the different ways that organisms interact. Note, too, that in order to interact, organisms must have some form of direct or indirect contact. Odum (1953) proposed that the interactions of two populations be 
defined by the outcomes for each. The types of interactions were referred to as mutualism, protocooperation, commensalism, neutralism, competition, amensalism, parasitism, and predation. While the terminology was developed for macroecology, examples of all of these types of interactions can be found in the natural world at both the macroscopic and microscopic level. And, because the development of plant diseases involves both plants and microbes, the interactions that lead to biological control take place at multiple levels of scale.

From the plant's perspective, biological control can be considered a net positive result arising from a variety of specific and non-specific interactions. Using the spectrum of Odum's concepts, we can begin to classify and functionally delineate the diverse components of ecosystems that contribute to biocontrol. Mutualism is an association between two or more species where both species derive benefit. Sometimes, it is an obligatory lifelong interaction involving close physical and biochemical contact, such as those between plants and mycorrhizal fungi. However, they are generally facultative and opportunistic. For example, bacteria in the genus Rhizobium can reproduce either in the soil or, to a much greater degree, through their mutualistic association with legume plants. These types of mutualism can contribute to biological control, by fortifying the plant with improved nutrition and/or by stimulating host defenses. Protocooperation is a form of mutualism, but the organisms involved do not depend exclusively on each other for survival. Many of the microbes isolated and classified as BCAs can be considered facultative mutualists involved in protocooperation, because survival rarely depends on any specific host and disease suppression will vary depending on the prevailing environmental conditions. Further down the spectrum, commensalism is a symbiotic interaction between two living organisms, where one organism benefits and the other is neither harmed nor benefited. Most plant-associated microbes are assumed to be commensals with regards to the host plant, because their presence, individually or in total, rarely results in overtly positive or negative consequences to the plant. And, while their presence may present a variety of challenges to an infecting pathogen, an absence of measurable decrease in pathogen infection or disease severity is indicative of commensal interactions. Neutralism describes the biological interactions when the population density of one species has absolutely no effect whatsoever on the other. Related to biological control, an inability to associate the population dynamics of pathogen with that of another organism would indicate neutralism. In contrast, antagonism between organisms results in a negative outcome for one or both. Competition within and between species results in decreased growth, activity and/or fecundity of the interacting organisms. Biocontrol can occur when non-pathogens compete with pathogens for nutrients in and around the host plant. Direct interactions that benefit one population at the expense of another also affect our understanding of biological control. Parasitism is a symbiosis in which two phylogenetically unrelated organisms coexist over a prolonged period of time. In this type of association, one organism, usually the physically smaller of the two (called the parasite) benefits and the other (called the host) is harmed to some measurable extent. The activities of various hyperparasites, i.e., those agents that parasitize plant pathogens, can result in biocontrol. And, interestingly, host infection and parasitism by relatively avirulent pathogens may lead to biocontrol of more virulent pathogens through the stimulation of host defense systems. Lastly, predation refers to the hunting and killing of one organism by another for consumption and sustenance. While the term predator typically refer to animals that feed at higher trophic levels in the macroscopic world, it has also been applied to the actions of microbes, e.g. protists, and mesofauna, e.g. fungal feeding nematodes and microarthropods, that consume pathogen biomass 
for sustenance. Biological control can result in varying degrees from all of these types of interactions, depending on the environmental context within which they occur. Significant biological control, as defined above, most generally arises from manipulating mutualisms between microbes and their plant hosts or from manipulating antagonisms between microbes and pathogens.

\section{Mechanisms of biological control}

Because biological control can result from many different types of interactions between organisms, researchers have focused on characterizing the mechanisms operating in different experimental situations. In all cases, pathogens are antagonized by the presence and activities of other organisms that they encounter. Here, we assert that the different mechanisms of antagonism occur across a spectrum of directionality related to the amount of interspecies contact and specificity of the interactions (Table 1). Direct antagonism results from physical contact and/or a high-degree of selectivity for the pathogen by the mechanism(s) expressed by the BCA(s). In such a scheme, hyperparasitism by obligate parasites of a plant pathogen would be considered the most direct type of antagonism because the activities of no other organism

Table 1. Types of interspecies antagonisms leading to biological control of plant pathogens.

\begin{tabular}{lll}
\hline Type & Mechanism & Examples \\
\hline Direct antagonism & Hyperparasitism/predation & Lytic/some nonlytic mycoviruses \\
& & Ampelomyces quisqualis \\
Lysobacter enzymogenes & Pasteuria penetrans \\
& & Trichoderma virens \\
\hline Mixed-path antagonism & Antibiotics & 2,4-diacetylphloroglucinol \\
& & Phenazines \\
\cline { 2 - 3 } & Lytic enzymes & Cyclic lipopeptides \\
& & Chitinases \\
\cline { 2 - 3 } & & Glucanases \\
\cline { 2 - 3 } & Unregulated waste products & Proteases \\
& & Ammonia \\
& Carbon dioxide \\
\cline { 2 - 3 } & Physical/chemical interference & Blockage of soil pores \\
& & Germination signals consumption \\
& & Molecular cross-talk confused \\
\hline Indirect antagonism & Competition & Exudates/leachates consumption \\
& & Siderophore scavenging \\
& & Physical niche occupation \\
\cline { 2 - 3 } & Induction of host resistance & Contact with fungal cell walls \\
& Detection of pathogen-associated, \\
& & molecular patterns \\
& & Phytohormone-mediated induction \\
\hline
\end{tabular}


would be required to exert a suppressive effect. In contrast, indirect antagonisms result from activities that do not involve sensing or targeting a pathogen by the BCA(s). Stimulation of plant host defense pathways by non-pathogenic BCAs is the most indirect form of antagonism. However, in the context of the natural environment, most described mechanisms of pathogen suppression will be modulated by the relative occurrence of other organisms in addition to the pathogen. While many investigations have attempted to establish the importance of specific mechanisms of biocontrol to particular pathosystems, all of the mechanisms described below are likely to be operating to some extent in all natural and managed ecosystems. And, the most effective BCAs studied to date appear to antagonize pathogens using multiple mechanisms. For instance, pseudomonads known to produce the antibiotic 2,4-diacetylphloroglucinol (DAPG) may also induce host defenses (Iavicoli et al. 2003). Additionally, DAPG-producers can aggressively colonize roots, a trait that might further contribute to their ability to suppress pathogen activity in the rhizosphere of wheat through competition for organic nutrients (Raaijmakers and Weller 2001).

\section{Hyperparasites and predation}

In hyperparasitism, the pathogen is directly attacked by a specific BCA that kills it or its propagules. In general, there are four major classes of hyperparasites: obligate bacterial pathogens, hypoviruses, facultative parasites, and predators. Pasteuria penetrans is an obligate bacterial pathogen of root-knot nematodes that has been used as a BCA. Hypoviruses are hyperparasites. A classical example is the virus that infects Cryphonectria parasitica, a fungus causing chestnut blight, which causes hypovirulence, a reduction in disease-producing capacity of the pathogen. The phenomenon has controlled the chestnut blight in many places (Milgroom and Cortesi 2004). However, the interaction of virus, fungus, tree, and environment determines the success or failure of hypovirulence. There are several fungal parasites of plant pathogens, including those that attack sclerotia (e.g. Coniothyrium minitans) while others attack living hyphae (e.g. Pythium oligandrum). And, a single fungal pathogen can be attacked by multiple hyperparasites. For example, Acremonium alternatum, Acrodontium crateriforme, Ampelomyces quisqualis, Cladosporium oxysporum, and Gliocladium virens are just a few of the fungi that have the capacity to parasitize powdery mildew pathogens (Kiss 2003). Other hyperparasites attack plant-pathogenic nematodes during different stages of their life cycles (e.g. Paecilomyces lilacinus and Dactylella oviparasitica). In contrast to hyperparasitism, microbial predation is more general and pathogen non-specific and generally provides less predictable levels of disease control. Some BCAs exhibit predatory behavior under nutrient-limited conditions. However, such activity generally is not expressed under typical growing conditions. For example, some species of Trichoderma produce a range of enzymes that are directed against cell walls of fungi. However, when fresh bark is used in composts, Trichoderma spp. do not directly attack the plant pathogen, Rhizoctonia solani. But in decomposing bark, the concentration of readily available cellulose decreases and this activates the chitinase genes of Trichoderma spp., which in turn produce chitinase to parasitize $R$. solani (Benhamou and Chet 1997).

\section{Antibiotic-mediated suppression}

Antibiotics are microbial toxins that can, at low concentrations, poison or kill other microorganisms. Most microbes produce and secrete one or more compounds with antibiotic 
activity. In some instances, antibiotics produced by microorganisms have been shown to be particularly effective at suppressing plant pathogens and the diseases they cause. Some examples of antibiotics reported to be involved in plant pathogen suppression are listed in Table 2. In all cases, the antibiotics have been shown to be particularly effective at suppressing growth of the target pathogen in vitro and/or in situ. To be effective, antibiotics must be produced in sufficient

Table 2. Some of antibiotics produced by BCAs

\begin{tabular}{|c|c|c|c|c|}
\hline Antibiotic & Source & Target pathogen & Disease & Reference \\
\hline $\begin{array}{l}\text { 2, 4-diacetyl- } \\
\text { phloroglucinol }\end{array}$ & $\begin{array}{l}\text { Pseudomonas } \\
\text { fluorescens F113 }\end{array}$ & Pythium spp. & Damping off & $\begin{array}{l}\text { Shanahan et al. } \\
\text { (1992), }\end{array}$ \\
\hline Agrocin 84 & $\begin{array}{l}\text { Agrobacterium } \\
\text { radiobacter }\end{array}$ & $\begin{array}{l}\text { Agrobacterium } \\
\text { tumefaciens }\end{array}$ & Crown gall & Kerr (1980) \\
\hline Bacillomycin D & $\begin{array}{l}\text { Bacillus subtilis } \\
\text { AU195 }\end{array}$ & Aspergillus flavus & $\begin{array}{l}\text { Aflatoxin } \\
\text { contamination }\end{array}$ & $\begin{array}{l}\text { Moyne et al. } \\
(2001)\end{array}$ \\
\hline $\begin{array}{l}\text { Bacillomycin, } \\
\text { fengycin }\end{array}$ & $\begin{array}{l}\text { Bacillus } \\
\text { amyloliquefaciens } \\
\text { FZB42 }\end{array}$ & $\begin{array}{l}\text { Fusarium } \\
\text { oxysporum }\end{array}$ & Wilt & $\begin{array}{l}\text { Koumoutsi et al. } \\
(2004)\end{array}$ \\
\hline Xanthobaccin A & $\begin{array}{l}\text { Lysobacter sp. } \\
\text { strain SB-K88 }\end{array}$ & $\begin{array}{l}\text { Aphanomyces } \\
\text { cochlioides }\end{array}$ & Damping off & $\begin{array}{l}\text { Islam et al. } \\
(2005)\end{array}$ \\
\hline Gliotoxin & $\begin{array}{l}\text { Trichoderma } \\
\text { virens }\end{array}$ & Rhizoctonia solani & Root rots & $\begin{array}{l}\text { Wilhite et al. } \\
(2001)\end{array}$ \\
\hline Herbicolin & $\begin{array}{l}\text { Pantoea } \\
\text { agglomerans C9-1 }\end{array}$ & Erwinia amylovora & Fire blight & $\begin{array}{l}\text { Sandra et al. } \\
(2001)\end{array}$ \\
\hline Iturin A & B. subtilis QST713 & $\begin{array}{l}\text { Botrytis cinerea } \\
\text { and } R . \text { solani }\end{array}$ & Damping off & $\begin{array}{l}\text { Paulitz and } \\
\text { Belanger (2001), } \\
\text { Kloepper et al. } \\
(2004)\end{array}$ \\
\hline Mycosubtilin & $\begin{array}{l}\text { B. subtilis } \\
\text { BBG100 }\end{array}$ & $\begin{array}{l}\text { Pythium } \\
\text { aphanidermatum }\end{array}$ & Damping off & $\begin{array}{l}\text { Leclere et al. } \\
(2005)\end{array}$ \\
\hline Phenazines & $\begin{array}{l}P . \text { fluorescens } \\
2-79 \text { and } 30-84\end{array}$ & $\begin{array}{l}\text { Gaeumannomyces } \\
\text { graminis var. tritici }\end{array}$ & Take-all & $\begin{array}{l}\text { Thomashow et } \\
\text { al. (1990) }\end{array}$ \\
\hline $\begin{array}{l}\text { Pyoluteorin, } \\
\text { pyrrolnitrin }\end{array}$ & P. fluorescens Pf-5 & $\begin{array}{l}\text { Pythium ultimum } \\
\text { and } R . \text { solani }\end{array}$ & Damping off & $\begin{array}{l}\text { Howell and } \\
\text { Stipanovic } \\
(1980)\end{array}$ \\
\hline $\begin{array}{l}\text { Pyrrolnitrin, } \\
\text { pseudane }\end{array}$ & $\begin{array}{l}\text { Burkholderia } \\
\text { cepacia }\end{array}$ & $\begin{array}{l}\text { R. solani and } \\
\text { Pyricularia oryzae }\end{array}$ & $\begin{array}{l}\text { Damping off } \\
\text { and rice blast }\end{array}$ & $\begin{array}{l}\text { Homma et al. } \\
\text { (1989) }\end{array}$ \\
\hline Zwittermicin A & $\begin{array}{l}\text { Bacillus cereus } \\
\text { UW85 }\end{array}$ & $\begin{array}{l}\text { Phytophthora } \\
\text { medicaginis and } \\
\text { P. aphanidermatum }\end{array}$ & Damping off & $\begin{array}{l}\text { Smith et al. } \\
\text { (1993) }\end{array}$ \\
\hline
\end{tabular}


quantities near the pathogen to result in a biocontrol effect. In situ production of antibiotics by several different biocontrol agents has been measured (Thomashow et al. 2002); however, the effective quantities are difficult to estimate because of the small quantities produced relative to the other, less toxic, organic compounds present in the phytosphere. And while methods have been developed to ascertain when and where biocontrol agents may produce antibiotics (Notz et al. 2001), detecting expression in the infection court is difficult because of the heterogenous distribution of plant-associated microbes and the potential sites of infection. In a few cases, the relative importance of antibiotic production by biocontrol bacteria has been demonstrated, where one or more genes responsible for biosynthesis of the antibiotics have been manipulated. For example, mutant strains incapable of producing phenazines (Thomashow and Weller 1988) or phloroglucinols (Keel et al. 1992, Fenton et al. 1992) have been shown to be equally capable of colonizing the rhizosphere but much less capable of suppressing soilborne root diseases than the corresponding wild-type and complemented mutant strains. Several biocontrol strains are known to produce multiple antibiotics which can suppress one or more pathogens. For example, Bacillus cereus strain UW85 is known to produce both zwittermycin (Silo-Suh et al. 1994) and kanosamine (Milner et al. 1996). The ability to produce multiple antibiotics probably helps to suppress diverse microbial competitors, some of which are likely to be plant pathogens. The ability to produce multiple classes of antibiotics, that differentially inhibit different pathogens, is likely to enhance biological control. More recently, Pseudomonas putida WCS358r strains genetically engineered to produce phenazine and DAPG displayed improved capacities to suppress plant diseases in field-grown wheat (Glandorf et al. 2001, Bakker et al. 2002).

\section{Lytic enzymes and other byproducts of microbial life}

Diverse microorganisms secrete and excrete other metabolites that can interfere with pathogen growth and/or activities. Many microorganisms produce and release lytic enzymes that can hydrolyze a wide variety of polymeric compounds, including chitin, proteins, cellulose, hemicellulose, and DNA. Expression and secretion of these enzymes by different microbes can sometimes result in the suppression of plant pathogen activities directly. For example, control of Sclerotium rolfsii by Serratia marcescens appeared to be mediated by chitinase expression (Ordentlich et al. 1988). And, a b-1,3-glucanase contributes significantly to biocontrol activities of Lysobacter enzymogenes strain C3 (Palumbo et al. 2005). While they may stress and/or lyse cell walls of living organisms, these enzymes generally act to decompose plant residues and nonliving organic matter. Currently, it is unclear how much of the lytic enzyme activity that can be detected in the natural environment represents specific responses to microbe-microbe interactions. It seems more likely that such activities are largely indicative of the need to degrade complex polymers in order to obtain carbon nutrition. Nonetheless, microbes that show a preference for colonizing and lysing plant pathogens might be classified as biocontrol agents. Lysobacter and Myxobacteria are known to produce copious amounts of lytic enzymes, and some isolates have been shown to be effective at suppressing fungal plant pathogens (Kobayashi and El-Barrad 1996, Bull et al. 2002). So, the lines between competition, hyperparasitism, and antibiosis are generally blurred. Furthermore, some products of lytic enzyme activity may contribute to indirect disease suppression. For example, oligosaccharides derived from fungal cell walls are known to be potent inducers of plant host defenses. Interestingly, Lysobacter enzymogenes strain $\mathrm{C} 3$ has been shown to induce plant host resistance to disease (Kilic-Ekici and 
Yuen 2003), though the precise activities leading to this induction are not entirely clear. The quantitative contribution of any and all of the above compounds to disease suppression is likely to be dependent on the composition and carbon to nitrogen ratio of the soil organic matter that serves as a food source for microbial populations in the soil and rhizosphere. However, such activities can be manipulated so as to result in greater disease suppression. For example, in postharvest disease control, addition of chitosan can stimulate microbial degradation of pathogens similar to that of an applied hyperparasite (Benhamou 2004). Chitosan is a non-toxic and biodegradable polymer of beta-1,4-glucosamine produced from chitin by alkaline deacylation. Amendment of plant growth substratum with chitosan suppressed the root rot caused by Fusarium oxysporum f. sp. radicis-lycopersici in tomato (Lafontaine and Benhamou 1996). Although the exact mechanism of action of chitosan is not fully understood, it has been observed that treatment with chitosan increased resistance to pathogens.

Other microbial byproducts also may contribute to pathogen suppression. Hydrogen cyanide $(\mathrm{HCN})$ effectively blocks the cytochrome oxidase pathway and is highly toxic to all aerobic microorganisms at picomolar concentrations. The production of $\mathrm{HCN}$ by certain fluorescent pseudomonads is believed to be involved in the suppression of root pathogens. $P$. fluorescens $\mathrm{CHA} 0$ produces antibiotics, siderophores and $\mathrm{HCN}$, but suppression of black rot of tobacco caused by Thielaviopsis basicola appeared to be due primarily to HCN production (Voisard et al. 1989). Howell et al. (1988) reported that volatile compounds such as ammonia produced by Enterobacter cloacae were involved in the suppression of Pythium ultimum-induced damping-off of cotton. While it is clear that biocontrol microbes can release many different compounds into their surrounding environment, the types and amounts produced in natural systems in the presence and absence of plant disease have not been well documented and this remains a frontier for discovery.

\section{Competition}

From a microbial perspective, soils and living plant surfaces are frequently nutrient limited environments. To successfully colonize the phytosphere, a microbe must effectively compete for the available nutrients. On plant surfaces, host-supplied nutrients include exudates, leachates, or senesced tissue. Additionally, nutrients can be obtained from waste products of other organisms such as insects (e.g. aphid honeydew on leaf surface) and the soil. While difficult to prove directly, much indirect evidence suggests that competition between pathogens and non-pathogens for nutrient resources is important for limiting disease incidence and severity. In general, soilborne pathogens, such as species of Fusarium and Pythium, that infect through mycelial contact are more susceptible to competition from other soil- and plant-associated microbes than those pathogens that germinate directly on plant surfaces and infect through appressoria and infection pegs. Genetic work of Anderson et al. (1988) revealed that production of a particular plant glycoprotein called agglutinin was correlated with potential of $P$. putida to colonize the root system. $P$. putida mutants deficient in this ability exhibited reduced capacity to colonize the rhizosphere and a corresponding reduction in Fusarium wilt suppression in cucumber (Tari and Anderson 1988). The most abundant nonpathogenic plant-associated microbes are generally thought to protect the plant by rapid colonization and thereby exhausting the limited available substrates so that none are available for pathogens to grow. For example, effective catabolism of nutrients in the spermosphere has been identified as a mechanism 
contributing to the suppression of Pythium ultimum by Enterobacter cloacae (van Dijk and Nelson 2000, Kageyama and Nelson 2003). At the same time, these microbes produce metabolites that suppress pathogens. These microbes colonize the sites where water and carboncontaining nutrients are most readily available, such as exit points of secondary roots, damaged epidermal cells, and nectaries and utilize the root mucilage.

Biocontrol based on competition for rare but essential micronutrients, such as iron, has also been examined. Iron is extremely limited in the rhizosphere, depending on soil pH. In highly oxidized and aerated soil, iron is present in ferric form (Lindsay 1979), which is insoluble in water ( $\mathrm{pH} 7.4)$ and the concentration may be as low as $10^{-18} \mathrm{M}$. This concentration is too low to support the growth of microorganisms, which generally need concentrations approaching $10^{-6} \mathrm{M}$. To survive in such an environment, organisms were found to secrete iron-binding ligands called siderophores having high affinity to sequester iron from the micro-environment. Almost all microorganisms produce siderophores, of either the catechol type or hydroxamate type (Neilands 1981). Kloepper et al. (1980) were the first to demonstrate the importance of siderophore production as a mechanism of biological control of Erwinia carotovora by several plant-growthpromoting Pseudomonas fluorescens strains A1, BK1, TL3B1 and B10. And, a direct correlation was established in vitro between siderophore synthesis in fluorescent pseudomonads and their capacity to inhibit germination of chlamydospores of $F$. oxysporum (Elad and Baker 1985, Sneh et al. 1984). As with the antibiotics, mutants incapable of producing some siderophores, such as pyoverdine, were reduced in their capacity to suppress different plant pathogens (Keel et al. 1989, Loper and Buyer 1991). The increased efficiency in iron uptake of the commensal microorganisms is thought to be a contributing factor to their ability to aggressively colonize plant roots and an aid to the displacement of the deleterious organisms from potential sites of infection.

\section{Induction of host resistance}

Plants actively respond to a variety of environmental stimuli, including gravity, light, temperature, physical stress, water and nutrient availability. Plants also respond to a variety of chemical stimuli produced by soil- and plant-associated microbes. Such stimuli can either induce or condition plant host defenses through biochemical changes that enhance resistance against subsequent infection by a variety of pathogens. Induction of host defenses can be local and/or systemic in nature, depending on the type, source, and amount of stimuli. Recently, phytopathologists have begun to characterize the determinants and pathways of induced resistance stimulated by biological control agents and other non-pathogenic microbes (Table 3). The first of these pathways, termed systemic acquired resistance (SAR), is mediated by salicylic acid (SA), a compound which is frequently produced following pathogen infection and typically leads to the expression of pathogenesis-related (PR) proteins. These PR proteins include a variety of enzymes some of which may act directly to lyse invading cells, reinforce cell wall boundaries to resist infections, or induce localized cell death. A second phenotype, first referred to as induced systemic resistance (ISR), is mediated by jasmonic acid (JA) and/or ethylene, which are produced following applications of some nonpathogenic rhizobacteria. Interestingly, the SA- and JA- dependent defense pathways can be mutually antagonistic, and some bacterial pathogens take advantage of this to overcome the SAR. For example, pathogenic strains of Pseudomonas 
Table 3. Bacterial determinants and types of host resistance induced by biocontrol agents

\begin{tabular}{|c|c|c|c|c|}
\hline Bacterial strain & Plant species & Bacterial determinant & Type & Reference \\
\hline $\begin{array}{l}\text { Bacillus mycoides } \\
\text { strain Bac J }\end{array}$ & Sugar beet & $\begin{array}{l}\text { Peroxidase, chitinase } \\
\text { and } \beta-1,3 \text {-glucanase }\end{array}$ & ISR & Bargabus et al. (2002) \\
\hline $\begin{array}{l}\text { Bacillus pumilus } \\
203-6\end{array}$ & Sugar beet & $\begin{array}{l}\text { Peroxidase, chitinase } \\
\text { and } \beta-1,3 \text {-glucanase }\end{array}$ & ISR & Bargabus et al. (2004) \\
\hline $\begin{array}{l}\text { Bacillus subtilis } \\
\text { GB03 and IN937a }\end{array}$ & Arabidopsis & 2,3-butanediol & ISR & Ryu et al. (2004) \\
\hline \multicolumn{5}{|l|}{$\begin{array}{l}\text { Pseudomonas } \\
\text { fluorescens strains }\end{array}$} \\
\hline \multirow[t]{2}{*}{ CHA0 } & Tobacco & Siderophore & SAR & Maurhofer et al. (1994) \\
\hline & Arabidopsis & Antibiotics (DAPG) & ISR & Iavicoli et al. (2003) \\
\hline \multirow[t]{3}{*}{ WCS374 } & Radish & Lipopolysaccharide & ISR & Leeman et al. (1995) \\
\hline & & Siderophore & & Leeman et al. (1995) \\
\hline & & Iron regulated factor & & Leeman et al. (1995) \\
\hline \multirow[t]{5}{*}{ WCS417 } & Carnation & Lipopolysaccharide & ISR & $\begin{array}{l}\text { Van Peer and Schipper } \\
\text { (1992) }\end{array}$ \\
\hline & Radish & Lipopolysaccharide & ISR & Leeman et al. (1995) \\
\hline & & Iron regulated factor & & Leeman et al. (1995) \\
\hline & Arabidopsis & Lipopolysaccharide & ISR & Van Wees et al. (1997) \\
\hline & Tomato & Lipopolysaccharide & ISR & Duijff et al. (1997) \\
\hline \multirow{3}{*}{$\begin{array}{l}\text { Pseudomonas } \\
\text { putida strains } \\
\text { WCS } 358\end{array}$} & Arabidopsis & Lipopolysaccharide & ISR & Meziane et al. (2005) \\
\hline & Arabidopsis & Lipopolysaccharide & ISR & Meziane et al. (2005) \\
\hline & & Siderophore & ISR & Meziane et al. (2005) \\
\hline BTP1 & Bean & Z,3-hexenal & ISR & Ongena et al. (2004) \\
\hline $\begin{array}{l}\text { Serratia } \\
\text { marcescens 90-166 }\end{array}$ & Cucumber & Siderophore & ISR & Press et al. (2001) \\
\hline
\end{tabular}

syringae produce coronatine, which is similar to JA, to overcome the SA-mediated pathway (He et al. 2004). Because the various host-resistance pathways can be activated to varying degrees by different microbes and insect feeding, it is plausible that multiple stimuli are constantly being received and processed by the plant. Thus, the magnitude and duration of host defense induction will likely vary over time. Only if induction can be controlled, i.e. by overwhelming or synergistically interacting with endogenous signals, will host resistance be increased. 
A number of strains of root-colonizing microbes have been identified as potential elicitors of plant host defenses. Some biocontrol strains of Pseudomonas sp. and Trichoderma sp. are known to strongly induce plant host defenses (Haas and Defago 2005, Harman 2004). In several instances, inoculations with plant-growth-promoting rhizobacteria (PGPR) were effective in controlling multiple diseases caused by different pathogens, including anthracnose (Colletotrichum lagenarium), angular leaf spot (Pseudomonas syringae pv. lachrymans and bacterial wilt (Erwinia tracheiphila). A number of chemical elicitors of SAR and ISR may be produced by the PGPR strains upon inoculation, including salicylic acid, siderophore, lipopolysaccharides, and 2,3-butanediol, and other volatile substances (Van Loon et al. 1998, Ongena et al. 2004, Ryu et al. 2004). Again, there may be multiple functions to such molecules blurring the lines between direct and indirect antagonisms. More generally, a substantial number of microbial products have been identified as elicitors of host defenses, indicating that host defenses are likely stimulated continually over the course of a plant's lifecycle. Excluding the components directly related to pathogenesis, these inducers include lipopolysaccharides and flagellin from Gram-negative bacteria; cold shock proteins of diverse bacteria; transglutaminase, elicitins, and $\beta$-glucans in Oomycetes; invertase in yeast; chitin and ergosterol in all fungi; and xylanase in Trichoderma (Numberger et al. 2004). These data suggest that plants would detect the composition of their plant-associated microbial communities and respond to changes in the abundance, types, and localization of many different signals. The importance of such interactions is indicated by the fact that further induction of host resistance pathways, by chemical and microbiological inducers, is not always effective at improving plant health or productivity in the field (Vallad and Goodman 2004).

\section{Microbial diversity and disease suppression}

Plants are surrounded by diverse types of mesofauna and microbial organisms, some of which can contribute to biological control of plant diseases. Microbes that contribute most to disease control are most likely those that could be classified competitive saprophytes, facultative plant symbionts and facultative hyperparasites. These can generally survive on dead plant material, but they are able to colonize and express biocontrol activities while growing on plant tissues. A few, like avirulent Fusarium oxysporum and binucleate Rhizoctonia-like fungi, are phylogenetically very similar to plant pathogens but lack active virulence determinants for many of the plant hosts from which they can be recovered. Others, like Pythium oligandrum are currently classified as distinct species. However, most are phylogenetically distinct from pathogens and, most often, they are subspecies variants of the same microbial groups. Due to the ease with which they can be cultured, most biocontrol research has focused on a limited number of bacterial (Bacillus, Burkholderia, Lysobacter, Pantoea, Pseudomonas, and Streptomyces) and fungal (Ampelomyces, Coniothyrium, Dactylella, Gliocladium, Paecilomyces, and Trichoderma) genera. Still, other microbes that are more recalcitrant to in vitro culturing have been intensively studied. These include mycorrhizal fungi, e.g. Pisolithus and Glomus spp. that can limit subsequent infections, and some hyperparasites of plant pathogens, e.g. Pasteuria penetrans which attack root-knot nematodes. Because multiple infections can and do take place in fieldgrown plants, weakly virulent pathogens can contribute to the suppression of more virulent pathogens, via the induction of host defenses. Lastly, there are the many general micro- and meso-fauna predators, such as protists, collembola, mites, nematodes, annelids, and insect larvae 
whose activities can reduce pathogen biomass, but may also facilitate infection and/or stimulate plant host defenses by virtue of their own herbivorous activities.

While various epiphytes and endophytes may contribute to biological control, the ubiquity of mycorrhizae deserves special consideration. Mycorrhizae are formed as the result of mutualist symbioses between fungi and plants and occur on most plant species. Because they are formed early in the development of the plants, they represent nearly ubiquitous root colonists that assist plants with the uptake of nutrients (especially phosphorus and micronutrients). The vesicular arbuscular mycorrhizal fungi (VAM, also known as arbuscular mycorrhizal or endomycorrhizal fungi) are all members of the zygomycota and the current classification contains one order, the Glomales, encompassing six genera into which 149 species have been classified (Morton and Benny 1990). Arbuscular mycorrhizae involve aseptate fungi and are named for characteristic structures like arbuscles and vesicles found in the root cortex. Arbuscules start to form by repeated dichotomous branching of fungal hyphae approximately two days after root penetration inside the root cortical cell. Arbuscules are believed to be the site of communication between the host and the fungus. Vesicles are basically hyphal swellings in the root cortex that contain lipids and cytoplasm and act as storage organ of VAM. These structures may present intra- and inter- cellular and can often develop thick walls in older roots. These thick walled structures may function as propagules (Biermann and Linderman 1983). During colonization, VAM fungi can prevent root infections by reducing the access sites and stimulating host defense. VAM fungi have been found to reduce the incidence of root-knot nematode (Linderman 1994). Various mechanisms also allow VAM fungi to increase a plant's stress tolerance. This includes the intricate network of fungal hyphae around the roots which block pathogen infections. Inoculation of apple-tree seedlings with the VAM fungi Glomus fasciculatum and G. macrocarpum suppressed apple replant disease caused by phytotoxic myxomycetes (Catska 1994). VAM fungi protect the host plant against root-infecting pathogenic bacteria. The damage due to Pseudomonas syringae on tomato may be significantly reduced when the plants are well colonized by mycorrhizae (Garcia-Garrido and Ocampo 1989). The mechanisms involved in these interactions include physical protection, chemical interactions and indirect effects (Fitter and Garbaye 1994). The other mechanisms employed by VAM fungi to indirectly suppress plant pathogens include enhanced nutrition to plants; morphological changes in the root by increased lignification; changes in the chemical composition of the plant tissues like antifungal chitinase, isoflavonoids, etc. (Morris and Ward 1992); alleviation of abiotic stress and changes in the microbial composition in the mycorrhizosphere (Linderman 1994). In contrast to VAM fungi, ectomycorrhizae proliferate outside the root surface and form a sheath around the root by the combination of mass of root and hyphae called a mantle. Disease protection by ectomycorrhizal fungi may involve multiple mechanisms including antibiosis, synthesis of fungistatic compounds by plant roots in response to mycorrhizal infection and a physical barrier of the fungal mantle around the plant root (Duchesne 1994). Ectomycorrhizal fungi like Paxillus involutus effectively controlled root rot caused by Fusarium oxysporum and Fusarium moniliforme in red pine. Inoculation of sand pine with Pisolithus tinctorius, another ectomycorrhizal fungus, controlled disease caused by Phytophthora cinnamomi (Ross and Marx 1972).

Because plant diseases may be suppressed by the activities of one or more plantassociated microbes, researchers have attempted to characterize the organisms involved in 
biological control. Historically, this has been done primarily through isolation, characterization, and application of individual organisms. By design, this approach focuses on specific forms of disease suppression. Specific suppression results from the activities of one or just a few microbial antagonists. This type of suppression is thought to be occurring when inoculation of a biocontrol agent results in substantial levels of disease suppressiveness. Its occurrence in natural systems may also occur from time to time. For example, the introduction of Pseudomonas fluorescens that produce the antibiotic 2,4-diacetylphloroglucinol can result in the suppression of various soilborne pathogens (Weller et al. 2002). However, specific agents must compete with other soil- and root-associated microbes to survive, propagate, and express their antagonistic potential during those times when the targeted pathogens pose an active threat to plant health. In contrast, general suppression is more frequently invoked to explain the reduced incidence or severity of plant diseases because the activities of multiple organisms can contribute to a reduction in disease pressure. High soil organic matter supports a large and diverse mass of microbes resulting in the availability of fewer ecological niches for which a pathogen competes. The extent of general suppression will vary substantially depending on the quantity and quality of organic matter present in a soil (Hoitink and Boehm 1999). Functional redundancy within different microbial communities allows for rapid depletion of the available soil nutrient pool under a large variety of conditions, before the pathogens can utilize them to proliferate and cause disease. For example, diverse seed-colonizing bacteria can consume nutrients that are released into the soil during germination thereby suppressing pathogen germination and growth (McKellar and Nelson 2003). Manipulation of agricultural systems, through additions of composts, green manures and cover crops is aimed at improving endogenous levels of general suppression.

\section{Biocontrol research, development, and adoption}

Biological control really developed as an academic discipline during the 1970s and is now a mature science supported in both the public and private sector (Baker 1987). Research related to biological control is published in many different scientific journals, particularly those related to plant pathology and entomology. Additionally, three academic journals are specifically devoted to the discipline (i.e. Biological Control, Biocontrol Research and Technology, and BioControl). In the United States, research funds for the discipline are provided primarily by several USDA programs. These include the Section 406 programs, regional IPM grants, Integrated Organic Program, IR-4, and several programs funded as part of the National Research Initiative. Monies also exist to stimulate the development of commercial ventures through the small business innovation research (SBIR) programs. Such ventures are intended to be conduits for academic research that can be used to develop new companies.

Much has been learned from the biological control research conducted over the past forty years. But, in addition to learning the lessons of the past, biocontrol researchers need to look forward to define new and different questions, the answers to which will help facilitate new biocontrol technologies and applications. Currently, fundamental advances in computing, molecular biology, analytical chemistry, and statistics have led to new research aimed at characterizing the structure and functions of biocontrol agents, pathogens, and host plants at the molecular, cellular, organismal, and ecological levels.. Some of the research questions that will 
advance our understanding of biological controls and the conditions under which it can be most fruitfully applied are listed in Table 4.

Table 4: Some current topics of biocontrol research and development and associated questions:

1. The ecology of plant-associated microbes

How are pathogens and their antagonists distributed in the environment?

Under what conditions do biocontrol agents exert their suppressive capacities?

How do native and introduced populations respond to different management practices?

What determines successful colonization and expression of biocontrol traits?

What are the components and dynamics of plant host defense induction?

2. Application of current strains/inoculant strategies

Can more effective strains or strain variants be found for current applications?

Will genetic engineering of microbes and plants be useful for enhancing biocontrol?

How can formulations be used to enhance activities of known biocontrol agents?

3. Discovering novel strains and mechanisms of action

Can previously uncharacterized microbes act as biological control agents?

What other genes and gene products are involved in pathogen suppression?

Which novel strain combinations work more effectively than individual agents?

Which signal molecules of plant and microbial origin regulate the expression of

biocontrol traits by different agents?

4. Practical integration into agricultural systems

Which production systems can most benefit from biocontrol for disease management?

Which biocontrol strategies best fit with other IPM system components?

Can effective biocontrol-cultivar combinations be developed by plant breeders?

Over the past fifty years, academic research has led to the development of a small but vital commercial sector that produces a number of biocontrol products. The current status of commercialization of biological control products has been reviewed recently (Fravel 2005). As in most industries, funding in the private sector research and development goes through cycles, but seems likely to increase in the years ahead as regulatory and price pressures for agrochemical inputs increase. Most of the commercial production of biological control agents is handled by relatively small companies, such as Agraquest, BioWorks, Novozymes, Prophyta, Kemira Agro. Occasionally, such companies are absorbed by or act as subsidiaries of multi-billion dollar agrochemical companies, such as Bayer, Monsanto, Syngenta, and Sumitomo. Total revenues of products used for biocontrol of plant diseases represented just a small fraction of the total pesticide market during the first few years of the $21^{\text {st }}$ century with total sales on the order of $\$ 10$ to 20 million dollars annually. However, significant expansion is expected over the next 10 years due to increasing petroleum prices, the expanded demand for organic food, and increased demand for "safer" pesticides in agriculture, forestry, and urban landscapes. 
Growers are interested in reducing dependence on chemical inputs, so biological controls (defined in the narrow sense) can be expected to play an important role in Integrated Pest Management (IPM) systems. A model describing the several steps required for a successful IPM has been developed (McSpadden Gardener and Fravel 2002). In this model, good cultural practices, including appropriate site selection, crop rotations, tillage, fertility and water management, provide the foundation for successful pest management by providing a fertile growing environment for the crop. The use of pest- and disease-resistant cultivars, developed through conventional breeding or genetic engineering, provides the next line of defense. However, such measures are not always sufficient to be productive or economically sustainable. In such cases, the next step would be to deploy biorational controls of insect pests and diseases These include BCAs, introduced as inoculants or amendments, as well as active ingredients directly derived from natural origins and having a low impact on the environment and non-target organisms. If these foundational options are not sufficient to ensure plant health and/or economically sustainable production, then less specific and more harmful synthetic chemical toxins can be used to ensure productivity and profitability. With the growing interest in reducing chemical inputs, companies involved in the manufacturing and marketing of BCAs should experience continued growth. However, stringent quality control measures must be adopted so that farmers get quality products. New, more effective and stable formulations also will need to be developed.

Most pathogens will be susceptible to one or more biocontrol strategies, but practical implementation on a commercial scale has been constrained by a number of factors. Cost, convenience, efficacy, and reliability of biological controls are important considerations, but only in relation to the alternative disease control strategies. Cultural practices (e.g. good sanitation, soil preparation, and water management) and host resistance can go a long way towards controlling many diseases, so biocontrol should be applied only when such agronomic practices are insufficient for effective disease control. As long as petroleum is cheap and abundant, the cost and convenience of chemical pesticides will be difficult to surpass. However, if the infection court or target pathogen can be effectively colonized using inoculation, the ability of the living organism to reproduce could greatly reduce application costs. In general, though, regulatory and cultural concerns about the health and safety of specific classes of pesticides are the primary economic drivers promoting the adoption of biological control strategies in urban and rural landscapes. Self-perpetuating biological controls (e.g. hypovirulence of the chestnut blight pathogen) are also needed for control of diseases in forested and rangeland ecosystems where high application rates over larger land areas are not economically-feasible. In terms of efficacy and reliability, the greatest successes in biological control have been achieved in situations where environmental conditions are most controlled or predictable and where biocontrol agents can preemptively colonize the infection court. Monocyclic, soilborne and postharvest diseases have been controlled effectively by biological control agents that act as bioprotectants (i.e. preventing infections). Specific applications for high value crops targeting specific diseases (e.g. fireblight, downy mildew, and several nematode diseases) have also been adopted. As research unravels the various conditions needed for successful biocontrol of different diseases, the adoption of BCAs in IPM systems is bound to increase in the years ahead. 


\section{References}

Anderson, A. J., Tari, P. H., and Tepper, C. S. 1988. Genetic studies on the role of an agglutinin in root colonization by Pseudomonas putida. Appl. Environ. Microbiol. 54:375-380.

Audenaert, K., Pattery, T., Cornelis, P., and Hofte, M. 2002. Induction of systemic resistance to Botrytis cinerea in tomato by Pseudomonas aeruginosa 7NSK2: role of salicylic acid, pyochelin and pyocyanin. Mol. Plant-Microbe Interact. 15:1147-1156.

Bargabus, R. L., Zidack, N. K., Sherwood, J. W., and Jacobsen, B. J. 2002. Characterization of systemic resistance in sugar beet elicited by a non-pathogenic, phyllosphere colonizing Bacillus mycoides, biological control agent. Physiol. Mol. Plant Pathol. 61:289-298.

Bargabus, R. L., Zidack, N. K., Sherwood, J. W., and Jacobsen, B. J. 2004. Screening for the identification of potential biological control agents that induce systemic acquired resistance in sugar beet. Biological Contr. 30:342-350.

Benhamou, N. 2004. Potential of the mycoparasite, Verticillium lecanii, to protect citrus fruit against Penicillium digitatum, the causal agent of green mold: A comparison with the effect of chitosan. Phytopathology 94:693-705.

Benhamou, N., and Chet, I. 1997. Cellular and molecular mechanisms involved in the intersection between Trichoderma harzianum and Pythium ultimum. Appl. Environ. Microbiol. 63:2095-2099.

Biermann, B., and Linderman, R. G. 1983. Use of vesicular-arbuscular mycorrhizal roots, intraradical vesicles and extraradical vesicles as inoculum. New Phytol. 95:97-105.

Bull, C. T., Shetty, K. G., and Subbarao, K. V. 2002. Interactions between Myxobacteria, plant pathogenic fungi, and biocontrol agents. Plant Dis. 86:889-896.

Catska, V. 1994. Interrelationship between vesicular-arbuscular mycorrhiza and rhizosphere microflora in apple replant disease. Biologia Plant. 36:99-104.

Chisholm, S. T., Coaker, G., Day, B., and Staskawicz, B. J. 2006. Host-microbe interactions: shaping the evolution of the plant immune response. Cell 124:803-814.

De Meyer, G., and Hofte, M. 1997. Salicylic acid produced by the rhizobacterium Pseudomonas aeruginosa 7NSK2 induces resistance to leaf infection by Botrytis cinerea on bean. Phytopathology 87:588-593.

Duchesne, L. C. 1994. Role of ectomycorrhizal fungi in biocontrol. Pages 27-45 in: Mycorrhizae and Plant Health. F. L. Pfleger and R. G. Linderman, eds. APS Press, St. Paul, MN.

Duijff, B. J., Gianinazzi-Pearson, V., and Lemanceau, P. 1997. Involvement of the outermembrane lipopolysaccharides in the endophytic colonization of tomato roots by biocontrol Pseudomonas fluorescens WCS417r. New Phytol. 135:325-334.

Elad, Y., and Baker, R. 1985. Influence of trace amounts of cations and siderophore-producing pseudomonads on chlamydospore germination of Fusarium oxysporum. Ecol. Epidemiol. 75:1047-1052.

Fitter, A. H., and Garbaye, J. 1994. Interactions between mycorrhizal fungi and other soil microorganisms. Plant Soil 159:123-132.

Garcia-Garrido, J. M., and Ocampo, J. A. 1989. Effect of VA mycorrhizal infection of tomato on damage caused by Pseudomonas syringae. Soil Biol. Biochem. 21:165-167.

Glandorf, D. C., Verheggen, P., Jansen, T., Jorritsma, J. W., Smit, E., Leefang, P., Wernars, K., Thomashow, L. S., Laureijs, E., Thomas-Oates, J. E., Bakker, P. A., and Van Loon, L. C. 2001. Effect of genetically modified Pseudomonas putida WCS358r on the fungal rhizosphere microflora of field-grown wheat. Appl. Environ. Microbiol. 67:3371-3378. 
Harman, G. E., Howell, C. R., Vitarbo, A., Chet, I., and Lorito, M. 2004. Trichoderma species opportunistic, avirulent plant symbionts. Nature Rev. Microbiol. 2:43-56.

He, P., Chintamanani, S., Chen, Z., Zhu, L., Kunkel, B. N., Alfano, J. R., Tang, X., and Zhou, J. M. 2004. Activation of a COI1-dependent pathway in Arabidopsis by Pseudomonas syringae type III effectors and coronatine. Plant J. 37:589-602.

Hoitink, H. A. J., and Boehm, M. J. 1999. Biocontrol within the context of soil microbial communities: a substrate dependent phenomenon. Annu. Rev. Phytopathol. 37:427-446.

Homma, Y., Kato, Z., Hirayama, F., Konno, K., Shirahama, H., and Suzui, T. 1989. Production of antibiotics by Pseudomonas cepacia as an agent for biological control of soilborne plant pathogens. Soil Biol. Biochem. 21:723-728.

Howell, C. R., Beier, R. C., and Stipanovic, R. D. 1988. Production of ammonia by Enterobacter cloacae and its possible role in the biological control of Pythium preemergence damping-off by the bacterium. Phytopathology 78:1075-1078.

Howell, C. R., and Stipanovic, R. D. 1980. Suppression of Pythium ultimum induced damping off of cotton seedlings by Pseudomonas fluorescens and its antibiotic, pyoluterin. Phytopathology 70:712-715.

Iavicoli, A., Boutet, E., Buchala, A., and Métraux, J. P. 2003. Induced systemic resistance in Arabidopsis thaliana in response to root inoculation with Pseudomonas fluorescens CHA0. Mol. Plant-Microbe Interact. 16:851-858.

Islam, T. M., Hashidoko, Y., Deora, A., Ito, T., and Tahara, S. 2005. Suppression of damping-off disease in host plants by the rhizoplane bacterium Lysobacter sp. strain SB-K88 is linked to plant colonization and antibiosis against soilborne peronosporomycetes. Appl. Environ. Microbiol. 71:3786-3796.

Kageyama, K., and Nelson, E.B. 2003. Differential inactiviation of seed exudates stimulation of Pythium ultimum sporangium germination by Enterobacter cloacae influences biological control efficacy on different plant species. Appl. Environ. Microbiol. 69:1114-1120.

Keel, C. Voisard, C., Berling, C. H., Kahir, G., and Defago, G. 1989. Iron sufficiency is a prerequisit for suppression of tobacco black root rot by Pseudomonas fluorescnes strain CHA0 under gnotobiotic contiditions. Phytopathology 79:584-589.

Kerr, A. 1980. Biological control of crown gall through production of agrocin 84. Plant Dis. 64: 25-30.

Kilic-Ekici, O., and Yuen, G. Y. 2003. Induced resistance as a mechanisms of biological control by Lysobacter enzymogenes strain C3. Phytopathology 93:1103-1110.

Kiss, L. 2003. A review of fungal antagonists of powdery mildews and their potential as biocontrol agents. Pest Manag. Sci. 59:475-483.

Kloepper, J. W., Leong, J., Teintze, M., and Schroth, M. N. 1980. Pseudomonas siderophores: A mechanism explaining disease suppression in soils. Current Microbiol. 4:317-320.

Kloepper, J. W, Ryu, C. M., and Zhang, S. 2004. Induce systemic resistance and promotion of plant growth by Bacillus spp. Phytopathology 94:1259-1266.

Koumoutsi, A., Chen, X. H., Henne, A., Liesegang, H., Gabriele, H., Franke, P., Vater, J., and Borris, R. 2004. Structural and functional characterization of gene clusters directing nonribosomal synthesis of bioactive lipopeptides in Bacillus amyloliquefaciens strain FZB42. J. Bact. 186:1084-1096.

Lafontaine, P. J., and Benhamon, N. 1996. Chitosan treatment: an emerging strategy for enhancing resistance of greenhouse tomato to infection by Fusarium oxysporum f.sp. radicilycopersici. Biocontrol Sci. Technol 6:111-124. 
Leclere, V., Bechet, M., Adam, A., Guez, J. S., Wathelet, B., Ongena, M., Thonart, P., Gancel, F., Chollet-Imbert, M., and Jacques, P. 2005. Mycosubtilin overproduction by Bacillus subtilis BBG100 enhances the organism's antagonistic and biocontrol activities. Appl. Environ. Microbiol. 71:4577-4584.

Leeman, M., Van Pelt, J. A., Den Ouden, F. M., Heinbroek, M., and Bakker, P. A. H. M. 1995. Induction of systemic resistance by Pseudomonas fluorescens in radish cultivars differing in susceptibility to Fusarium wilt, using novel bioassay. Eur. J. Plant Pathol. 101:655-664.

Leeman, M., Van Pelt, J. A., Hendrickx, M. J., Scheffer, R. J., and Bakker, P. A. H. M. 1995. Biocontrol of Fusarium wilt of radish in commercial greenhouse trials by seed treatment with Pseudomonas fluorescens WCS374. Phytopathol 85:1301-1305.

Linderman, R. G. 1994. Role of AM fungi in biocontrol. Pages 1-25 in: Mycorrhizae and Plant Health. F. L. Pfleger and R. G. Linderman, eds. APS Press, St. Paul, MN.

Lindsay, W. L. 1979. Chemical Equilibria in Soils. John Wiley \& Sons, Inc., New York.

Loper, J. E., and Buyer, J. S. 1991. Siderophores in microbial interactions of plant surfaces. Mol. Plant-Microbe Interact. 4:5-13.

Maurhofer, M., Hase, C., Meuwly, P., Metraux, J. P., and Defago, G. 1994. Induction of systemic resistance to tobacco necrosis virus by the root-colonizing Pseudomonas fluorescens strain CHA0: influence of the gacA gene and of pyoverdine production. Phytopathology 84:139-146.

McKellar, M. E., and Nelson, E. B. 2003. Compost-induced suppression of Pythium damping-off is mediated by fatty-acid-metabolizing seed-colonizing microbial communities. Appl. Environ. Microbiol. 69:452-460.

McSpadden Gardener, B., and Fravel, D. 2002. Biological control of plant pathogens: Research commercialization, and application in the USA. Online. Plant Health Progress doi:10.1094/PHP-2002-0510-01-RV.

Meziane, H., Van der Sluis, I., Van Loon, L. C., Hofte, M., and Bakker, P. A. H. M. 2005. Determinants of Pseudomonas putida WCS358 involved in inducing systemic resistance in plants. Mol. Plant Pathol. 6:177-185.

Milgroom, M. G., and Cortesi, P. 2004. Biological control of chestnut blight with hypovirulence: a critical analysis. Annu. Rev. Phytopathol. 42:311-338.

Morris, P. F., and Ward, E. W. R. 1992. Chemoattraction of zoospores of the plant soybean pathogen, Phytophthora sojae, by isoflavones. Physiol. Mol. Plant Pathol. 40:17-22.

Morton, J. B., and Benny, G. L. 1990. Revised classification of arbuscular mycorrhizal fungi (zygomycetes): a new order glomales, two new suborders, glomineae and gigasporineae and gigasporaceae, with an amendation of glomaceae. Mycotaxon 37:471-491.

Moyne, A. L., Shelby, R., Cleveland, T. E., and Tuzun, S. 2001. Bacillomycin D: an iturin with antifungal activity against Aspergillus flavus. J. Appl. Microbiol. 90:622-629.

Neilands, J. B. 1981. Microbial iron compounds. Annu. Rev. Biochem. 50:715-731.

Notz, R., Maurhofer, M., Schnider-Keel, U., Duffy, B., Haas, D., and Defago, G. 2001. Biotic factors affecting expression of the 2,4-diacetylphloroglucinol biosynthesis gene phlA in Pseudomonas fluorescens biocontrol strain CHA0 in the rhizosphere. Phytopathology 91:873-881.

Numberger, T., Brunner, F., Kemmerling, B., and Piater, L. 2004. Innate immunity in plants and animals: striking similarities and obvious differences. Immunological Rev. 198:249-266.

Odum, E. P. 1953. Fundamentals of Ecology. W. B. Saunders, Philadelphia / London. 
Ongena, M., Duby, F., Rossignol, F., Fouconnier, M. L., Dommes, J., and Thonart, P. 2004. Stimulation of the lipoxygenase pathway is associated with systemic resistance induced in bean by a nonpathogenic Pseudomonas strain. Mol. Plant-Microbe Interact. 17:1009-1018.

Ordentlich, A., Elad, Y., Chet, I. 1988. The role of chitinase of Serratia marcescens in the biocontrol of Sclerotium rolfsii. Phytopathology 78:84-88.

Palumbo, J. D., Yuen, G. Y., Jochum, C. C., Tatum, K., and Kobayashi, D. Y. 2005. Mutagenesis of beta-1,3-glucanase genes in Lysobacter enzymogenes strain C3 results in reduced biological control activity toward Bipolaris leaf spot of tall fescue and Pythium damping-off of sugar beet. Phytopathology 95: 701-707.

Paulitz, T. C., and Belanger, R. R. 2001. Biological control in greenhouse systems. Annu. Rev. Phytopathol. 39:103-133.

Pieterse, C. M. J., Van Wees, S. C. M., Ton, J., Van Pelt, J. A., and Van Loon, L. C. 2002. Signalling in rhizobacteria induced systemic resistance in Arabidopsis thaliana. Plant Biol. 4:535-544.

Press, C. M., Loper, J. E., and Kloepper, J. W. 2001. Role of iron in rhizobacteria mediated induced systemic resistance of cucumber. Phytopathology 91:593-598.

Raaijmakers, J. M., Vlami, M., and De Souza, Jorge T. 2002. Antibiotic production by bacterial biocontrol agents. Anton. van Leeuw. 81:537-547.

Ross, E. W., and Marx, D. M. 1972. Susceptibility sand pine to Phytophthora cinnamomi. Phytopathology 62:1197-1200.

Ryu, C. M., Farag, M. A., Hu, C. H., Reddy, M. S., Kloepper, J.W., and Pare, P. W. 2004. Bacterial volatiles induce systemic resistance in Arabidopsis. Plant Physiol. 134:1017-1026.

Sandra, A. I., Wright, C. H., Zumoff, L. S., and Steven, V. B. 2001. Pantoea agglomerans strain EH318 produces two antibiotics that inhibit Erwinia amylovora in vitro. Appl. Environ. Microbiol. 67:282-292.

Shanahan, P., O'Sullivan, D. J., Simpson, P., Glennon, J. D., and O'Gara, F. 1992. Isolation of 2,4-Diacetylphloroglucinol from a fluorescent pseudomonad and investigation of physiological parameters influencing its production. Appl. Environ. Microbiol. 58:353-358.

Smith, K. P., Havey, M. J., and Handelsman, J. 1993. Suppression of cottony leak of cucumber with Bacillus cereus strain UW85. Plant Dis. 77:139-142.

Sneh, B., Dupler, M., Elad, Y., and Baker, R. 1984. Chlamydospore germination of Fusarium oxysporum f. sp. cucumerinum as affected by fluorescent and lytic bacteria from Fusarium suppressive soils. Phytopathology 74:1115-1124.

Tari, P.H., and Anderson, A. J. 1988. Fusarium wilt suppression and agglutinability of Pseudomonas putida. Appl. Environ. Microbiol. 54:2037-2041.

Thomashow, L. S., Bonsall, R. F., and Weller, D. M. 2002. Antibiotic production by soil and rhizosphere microbes in situ. Pages 638-647 in: Manual of Environmental Microbiology (2 ${ }^{\text {nd }}$ ed.), ASM Press, Washington DC.

Thomashow, L. S., and Weller, D. M. 1988. Role of a phenazine antibiotic from Pseudomonas fluorescens in biological control of Gaeumannomyces graminis var. tritici. J. Bact. 170:3499-3508.

Thomashow, L. S., Weller, D. M., Bonsall, R. F., and Pierson, L. S. III. 1990. Production of the antibiotic phenazine-1-carboxylic acid by fluorescent pseudomonas in the rhizosphere of wheat. Appl. Environ. Microbiol. 56:908-912.

US Congress Office of Technology Assessment. 1995. Biologically-based technologies for pest control. OTA-ENV-636. US Government Printing Office, Washington, DC. 
Vallad, G. E., and Goodman, R. M. 2004. Systemic acquired resistance and induced systemic resistance in conventional agriculture: review and interpretation. Crop Sci. 44:1920-1934.

van Dijk, K., and Nelson, E. B. 2000. Fatty acid competition as a mechanism by which Enterobacter cloacae suppresses Pythium ultimum sporangium germination and dampingoff. Appl. Environ. Microbiol. 66:5340-5347.

Van Loon, L. C., Bakker, P. A. H. M., and Pieterse, C. M. J. 1998. Systemic resistance induced by rhizosphere bacteria. Annu. Rev. Phytopathol. 36:453-483.

Van Peer, R., and Schippers, B. 1992. Lipopolysaccharides of plant-growth promoting Pseudomonas sp. strain WCS417r induce resistance in carnation to Fusarium wilt. Neth. J. Plant Pathol. 98:129-139.

Van Wees, S. C. M., Pieterse, C. M. J., Trijssenaar, A., Van't Westende, Y., and Hartog, F. 1997. Differential induction of systemic resistance in Arabidopsis by biocontrol bacteria. Mol. Plant-Microbe Interact. 10:716-724.

Voisard, C., Keel, C., Haas, D., and Defago, G. 1989. Cyanide production by Pseudomonas fluorescens helps suppress black root of tobacco under gnotobiotic conditions. EMBO J. 8:351-358.

Weller, D. M., and Cook, R. J. 1983. Suppression of take-all of wheat by seed treatments with fluorescent pseudomonads. Phytopathology 73:463-469.

Weller, D. M., Raaijmakers, J., McSpadden Gardener, B., and Thomashow, L. M. 2002. Microbial populations responsible for specific soil suppressiveness to plant pathogens. Annu. Rev. Phytopathol. 40:309-348.

Wilhite, S. E., Lunsden, R. D., and Strancy, D. C. 2001. Peptide synthetase gene in Trichoderma virens. Appl. Environ. Microbiol. 67:5055-5062. 


\section{Suggested Readings}

The following bibliography contains published texts that the authors feel have various strengths and weaknesses related to experimental design, implementation, data presentation, and interpretation of biocontrol research. It is intended to stimulate critical reflection and discussion about various topics related to biocontrol and publication of scientific research. Titles in italics are review articles that present a general introduction to the topic. Those in plain text are suggested readings for classroom discussion and critique.

Instructors are encouraged to have students select one or two papers to review per class session. The student should present a 15 min summary of the study objectives, key observations, and the authors' interpretations. Discussion should then ensue among all present regarding i) the quality of the paper in terms of clarity, ii) the adequacy of the experimental design and conclusions drawn from the data by the authors, iii) the knowledge and insights gained by the students, and, iv) the novelty and significance of the work based on the assigned/associated review articles. In directing such discussions, instructors are encouraged to advise students to focus on the strengths of each work and their response to it in order to develop the habit and posture of positive criticism.

\section{Book References}

Biological Control of Crop Diseases. 2002. S. Gnanamanickam ed. Marcel Dekker: New York, $N Y$.

Cook, R. J., and Baker, K. F. 1983. The Nature and Practice of Biological Control of Plant Pathogens. American Phytopathological Society, St. Paul, MN.

\section{Introduction and History}

Baker, K. F. 1987. Evolving concepts of biological control of plant pathogens. Annu. Rev. Phytopathol. 25:67-85.

Haas, D. and Defago, G. 2005. Biological control of soil-borne pathogens by fluorescent pseudomonads. Nature Rev. Microbiol. 3:307-319.

Harman, G. E., Howell, C. R. Viterbo, A., Chet, I, and Lorito, M. 2004 Trichoderma speciesopportunistic, avirulent plant symbionts. Nature Rev. Microbiol. 2:43-56.

McSpadden Gardener, B. B., and Fravel, D. R. 2002. Biological control of plant pathogens: Research, commercialization, and application in the USA. Online. Plant Health Progress doi:10.1094/PHP-2002-0510-01-RV. (Also online http://www.apsnet.org/online/feature/biocontrol/top.html)

\section{Mechanisms}

Chisholm, S. T., Coaker, G., Day, B., and Staskawicz, B. J. 2006. Host-microbe interactions: shaping the evolution of the plant immune response. Cell 124:803-814.

Raaijmakers, J. M., Vlami, M., and De Souza, J. T. 2002. Antibiotic production by bacterial biocontrol agents. Anton. van Leeuw. 81:537-547. 
Jones, R. W., and Prusky, D. 2002. Expression of an antifungal peptide in Saccharomyces: A new approach for biological control of the post harvest disease caused by $C$. coccodes. Phytopathology 92:33-37.

Ryu, C. M., Farag, M. A., Hu, C. H., Reddy, M. S., Wei, H. X., Paré, P. W., and Kloepper, J. W. 2003. Bacterial volatiles promote growth in Arabidopsis. Proc. Nat. Acad. Sci. 100:49274932.

Shishido, M., Miwa, C., Usami, T., Amemiya, Y., and Johnson, K. B. 2005. Biological control efficiency of fusarium wilt of tomato by nonpathogenic $F$. oxysporum Fo-B2 in different environments. Phytopathology 95:1072-1080.

Silva, H. S. A., Romeiro, R. S., Macagnan, D., Halfeld-Vieira, B. A., Pereira, M. C. B., and Mounteer, A. 2004. Rhizobacterial induction of systemic resistance in tomato plants: nonspecific protection and increase in enzyme activities. Biol. Control. 29:288-295.

Vallad, G. E., and Goodman, R. M. 2004. Systemic acquired resistance and induced systemic resistance in conventional agriculture: review and interpretation. Crop Sci. 44:1920-1934.

van Dijk, K., and Nelson, E. B. 2000. Fatty acid competition as a mechanism by which Enterobacter cloacae suppresses Pythium ultimum sporangium germination and dampingoff. Appl. Environ. Microbiol. 66:5340-5347.

\section{Microbial Diversity}

Leadbetter, E.R. 2002. Prokaryotic Diversity: Form, Ecophysiology, and Habitat. Pages 19-32 in: Manual of Environmental Microbiology ( $2^{\text {nd }}$ ed.), ASM Press, Washington DC.

Berg, G., Krechel, A., Ditz, M., Sikora, R. A., Ulrich, A., and Hallmann, J. 2005. Endophytic and ectophytic potato-associated bacterial communities differ in structure and antagonistic function against plant pathogenic fungi. FEMS Microbiol. Ecol. 51:215-229.

Joshi, R., and McSpadden Gardener, B. 2006. Identification and characterization of novel genetic markers associated with biological control activities of Bacillus subtilis. Phytopathology 96:145-154.

Yin, B., Valinsky, L. Gao, X., Becker, J. O., and Borneman, J. 2003. Bacterial rRNA genes associated with soil suppressiveness against the plant-parasitic nematode Heterodera schachtii. Appl. Environ. Microbiol. 69: 1573-1580.

Yin, B., Valinsky, L., Gao, X., Becker, J. O., and Borneman, J. 2003. Identification of fungal rDNA associated with soil suppressiveness against Heterodera schachtii using oligonucleotide fingerprinting. Phytopathology 93:1006-1013.

\section{Ecology of biocontrol}

Kerry, B. 2000. Rhizosphere interactions and the exploitation of microbial agents for the biological control of plant parasitic nematodes. Annu. Rev. Phytopathol. 38:423-441.

Anderson, L. M., Stockwell, V. O., and Loper, J. E. 2004. An extracellular protease of Pseudomonas fluorescens inactivates antibiotics of Pantoea agglomerans. Phytopathology 94:1228-1234.

Kovach, J., Petzoldt, R., and Harman, G. E. 2000. Use of honey and bumble bees to disseminate Trichoderma harzianum 1295-22 to strawberries for Botrytis control. Biol. Control 18:235242. 
McSpadden Gardener, B., and Weller, D. 2001. Changes in populations of rhizosphere bacteria associated with take-all disease of wheat. Appl. Environ. Microbiol. 67:4414-4425.

Phillips, D. A., Fox, T. C., King, M. D., Bhuvaneswari, T. V., and Teuber, L. R. 2004. Microbial products trigger amino acid exudation from plant roots. Plant Physiol. 136:2887-2994.

Schouten, A., Van den Berg, G., Edel-Hermann, V., Steinberg, C., Gautheron, N., Alabouvette, C., De Vos, C. H., Lemanceau, P., and Raaijmakers, J. M. 2004. Defense responses of Fusarium oxysporum to 2,4-DAPG, a broad spectrum antibiotic produced by Pseudomonas fluorescens. Mol. Plant-Microbe Interact. 17:1201-1211.

\section{Soilborne disease control}

Sikora, R. 1992. Management of antagonistic potential in agricultural ecosystems for the biological control of plant parasitic nematodes. Annu. Rev. Phytopathol. 30:245-270.

Weller, D. M., Raaijmakers, J., McSpadden Gardener, B., and Thomashow, L. S. 2002. Microbial populations responsible for specific soil suppressivenes. Annu. Rev. Phytopathol. 40:309-348.

Cook, R. J., Weller, D. M., Youssef El-Banna, A., Vakoch, D., and Zhang, H. 2002. Yield responses of direct-seeded wheat to rhizobacteria and fungicide seed treatments. Plant Dis. 86:780-784.

Ramette, A., Moënne-Loccoz, Y., and Défago, G. 2003. Prevalence of fluorescent pseudomonads producing antifungal phloroglucinols and/or hydrogen cyanide in soils naturally suppressive or conducive to tobacco root rot. FEMS Microb. Ecol. 44:35-43.

McSpadden Gardener, B. B., Gutierrez, L. J., Joshi, R., Edema, R., and Lutton, E. 2005. Distribution of $p h l D^{+}$bacteria in corn and soybean fields. Phytopathology 95:715-724.

Scheuerell, S. J., Sullivan, D. M., and Mahaffee, W. F. 2005. Suppression of seedling dampingoff caused by Pythium ultimum, P. irregulare, and Rhizoctonia solani in container media amended with a diverse range of Pacific Northwest compost sources. Phytopathology 95:306-315.

\section{Foliar and above-ground disease control}

Andrews, J. 1992. Biological control in the phyllosphere. Annu. Rev. Phytopathol. 30:603-633.

Milgroom, M., and Cortesi, P. 2004. Biological control of chestnut blight with hypoviulence: A critical review. Annu. Rev. Phytopathol. 42:311-338.

Johnson, K. B., Stockwell, V. O., Sawyer, T. L., and Sugar, D. 2000. Assessment of environmental factors influencing growth and spread of Pantoea agglomerans on and among blossoms of pear and apple. Phytopathology 90:1285-1294.

Kessel, G. J. T., Köhl, J., Powell, J. A., Rabbinge, R., and Van der Werf, W. 2005. Modeling spatial characteristics in the biological control of fungi at the leaf scale: Competitive substrate colonization by Botrytis cinerea and the saprophytic antagonist Ulocladium atrum. Phytopathology 95:439-448.

Stockwell, V. O., Johnson, K. B., Sugar, D., and Loper, J. E. 2002. Antibiosis contributes to biological control of fire blight by Pantoea agglomerans strain Eh252 in orchards. Phytopathology 92:1202-1209.

Thomson, S. V., and Gouk, S. C. 2003. Influence of age of apple flowers on growth of Erwinia amylovora and biological control agents. Plant Dis. 87:502-509. 


\section{Postharvest disease control}

Janisiewicz, W. and Korsten, L. 2002. Biological control of postharvest diseases of fruits. Annu. Rev. Phytopathol. 40:411-441.

de Capdeville, G., Wilson, C. L., Beer, S. V., and Aist, J. R. 2002. Alternative disease control agents induce resistance to blue mold in harvested 'Red Delicious' apple fruit. Phytopathology 92:900-908.

El-Ghaouth, A., Smilanick, J. L., Brown, G. E., Ippolito, A., Wisniewski, M., and Wilson, C. L. 2000. Application of Candida saitoana and glycolchitosan for the control of postharvest diseases of apple and citrus fruit under semi-commercial conditions. Plant Dis. 84:243-248.

Janisiewicz, W. J., and Peterson, D. L. 2004. Susceptibility of the stem pull area of mechanically harvested apples to blue mold decay and its control with a biocontrol agent. Plant Dis. 88:662-664.

\section{Commercialization}

Fravel, D. 2005. Commercialization and implementation of biocontrol. Annu. Rev. Phytopathol. 43:337-359.

Paulitz, T., and Belanger, R. 2001. Biological control in greenhouse systems. Annu. Rev. Phytopathol. 39:103-133.

Elliott, M. L., Jardin, E. A. D., Batson, W. E., Caceres, J., Brannen, P. M., Howell, C. R., Benson, D. M., Conway, K. E., Rothrock, C. S., Schneider, R. W., Ownley, B. H., Canaday, C. H., Keinath, A. P., Huber, D. M., Sumner, D. R., Motsenbocker, C. E., Thaxton, P. M., Cubeta, M. A., Adams, P. D, Backman, P. A., Fajardo, J., Newman, M. A., and Pereira, R. M. 2001. Viability and stability of biological control agents on cotton and snap bean seeds. Pest Mgmt. Sci. 57:695-706.

Batson, Jr., W. E., Caceres, J., Benson, M., Cubeta, M. A., Elliott, M. L., Huber, D. M., Hickman, M. V., McLean, K. S., Ownley, B., Newman, M., Rothrock, C. S., Rushing, K. W., Kenny, D. S., and P. Thaxton. 2001. Biological seed treatment evalutations for control of the seedling disease complex of cotton, 2000. B\&C Tests 16:F12.

Batson, Jr., W.E., Caceres, J., Benson, M., Cubeta, M. A., Elliott, M. L., Huber, D. M., Hickman, M. V., Keinath, A. P., Dubose, V., McLean, K. S., Ownley, B., Canaday, C., Rushing, K. W., and Kenny, D. S. 2001. Biological seed treatment evalutations for control of the seedling disease complex of snap bean, 2000. B\&C Tests 16:V81

Bargabus, R. L., Zidack, N. K., Sherwood, J. W., and Jacobsen, B. J. 2004. Screening for the identification of potential biological control agents that induce systemic acquired resistance in sugarbeet. Biol. Control 30:342-350.

Mercier, J., and Lindow, S. E. 2001. Field performance of antagonistic bacteria identified in a novel assay for biological control of fireblight. Biol. Control 22:66-71.

Wang, H., Hwang, S. F., Chang, K. F., Turnbull, G. D., and Howard, R. J. 2003. Suppression of important pea diseases by bacterial antagonists. BioControl 48:447-460. 


\section{Regulations and Risk Assessment}

Van Lenteren, J.C., Babendreier, D., Bigler, F., Burgio, G., Hokkanen, H. M. T., Kuske, S., Loomans, A. J. M., Menzler-Hokkanen, I., Van Rijn, P. C. J., Thomas, M. B., Tommasini, M. G., and Zeng, Q.- Q. 2003. Environmental risk assessment of exotic natural enemies used in inundative biological control. BioControl 48:3-38.

Bloom, B., Ehlers, R., Haukeland-Salinas, S., Hoddanen, H., Jung, K., Kuhlmann, U., Ravensberg, W., Strasser, H., Warrior, P., and Wilson, M. 2003. Biological control agents: Safety and regulatory policy. BioControl 48:477-484.

Bankhead, S. B., Landa, B. B., Lutton, E., Weller, D. M., and McSpadden Gardener, B. B. 2004. Minimal changes in rhizosphere population structure following root colonization by wild type and transgenic biocontrol strains. FEMS Microb. Ecol 49:307-318.

Timms-Wilson, T. M., Kilshaw, K., and Bailey, M. J. 2004. Risk assessment for engineered bacteria used in biocontrol of fungal disease in agricultural crops. Plant Soil 266:57-67.

U.S. Environmental Protection Agency. 1996. Microbial pesticide test guidelines. OPPTS 885.0001. Overview for microbial pest control agents. EPA 712-C-96-280.

U.S. Environmental Protection Agency. 1996. Microbial pesticide test guidelines. OPPTS 885.5000. Background for microbial pesticide testing. EPA 712-C-96-056.

\section{Integration}

Cook, R. 1993. Making greater use of microbial inoculants in agriculture. Annu. Rev. Phytopathol. 31:53-80.

Rodrigues, L. C. and Niemeyer, H. M. 2005. Integrated pest management, semiochemicals and microbial pest-control agents in Latin American agriculture. Crop Protection 24:615-623.

Jacobsen, B. J., Zidack, N. K., and Larson, B. J. 2004. The role of Bacillus-based biological control agents in integrated pest management systems: Plant diseases. Phytopathology 94:1272-1275.

Guetsky, R., Shtienberg, D., Elad, Y., and Dinoor, A. 2001. Combining biocontrol agents to reduce the variability of biological control. Phytopathology 91:621-627.

Raupach, G. S., and Kloepper, J. W. 1998. Mixtures of PGPR enhance biological control of multiple cucumber pathogens. Phytopathology 88:1158-1164.

Spadaro, D., and Gullino, M. L. 2005. Improving the efficacy of biocontrol agents against soilborne pathogens. Crop Prot. 24:601-613.

Stevens, C., Khan, V. A., Rodriguez-Kabana, R., Ploper, L. D., Backman, P. A., Collins, D. J., Brown, J. E., Wilson, M. A., and Igwegbe, E. C. K. 2003. Integration of soil solarization with chemical, biological, and cultural control for the management of soilborne disease of vegetables. Plant Soil 253:493-506. 